Situs Jurnal : $\underline{\text { http://ejournal.stiepancasetia.ac.id/index.php/jieb }}$

Jilid 5 Nomor 3 November 2019

Hal $353-361$

\title{
PENGARUH PENDIDIKAN DAN PELATIHAN TERHADAP KINERJA KARYAWANPADA UD. YAMAHA ISTANA SEPEDA BALANGAN
}

\section{Haris Irawan* \& Imansyah}

Abstract: The study aims to determine the effect of education and training on employee performance in the service division UD. Yamaha Bike Palace Balangan. The sampling method done by directly selecting 36 employees. Data collection methods used direct interviews with parties involved with the problem being discussed and provide questionnaires to employees in accordance with the research conducted. Data were analyzed using qualitative and quantitative methods simple regression analysis formulas, T-Tests, and Determination Coefficient Test (R2) with helped by SPPS 18 software. Based on the analysis results, the regression equation: $\mathrm{Y}=$ $5.221+0.946 \mathrm{X}$. The results of this study: T-test variables of education and training are known have a significant positive effect on employee performance, because the significance level is $5 \%$ greater than $t$-table $(13,443>2,032)$. The determination coefficient $(\mathrm{R} 2)$ is 0.842 , which means the ability education and training variable $(\mathrm{X})$ can affect the employee performance variable (Y) by $84.2 \%$.

Keywords: education, training, employee performance

Abstrak: Penelitian bertujuan untuk mengetahui pengaruh pendidikan dan pelatihan terhadap kinerja karyawan di divisi layanan UD. Yamaha Istana Sepeda Balangan. Metode pengambilan sampel dilakukan dengan memilih langsung 36 karyawan. Metode pengumpulan data yang digunakan adalah wawancara langsung dengan pihak-pihak yang terlibat dengan masalah yang sedang dibahas dan memberikan kuesioner kepada karyawan sesuai dengan penelitian yang dilakukan. Data dianalisis menggunakan metode kualitatif dan metode kuantitatif menggunakan rumus analisis regresi sederhana, Uji-T, dan Uji Koefisien Determinasi (R2) dengan bantuan perangkat lunak SPPS 18. Berdasarkan hasil analisis, persamaan regresi adalah: $\mathrm{Y}=5,221+0,946 \mathrm{X}$. Hasil dari penelitian ini adalah: T-test variabel pendidikan dan pelatihan diketahui berpengaruh positif signifikan terhadap kinerja karyawan, karena taraf signifikansi $5 \%$ lebih besar dari t-tabel (13.443> 2.032). Koefisien determinasi (R2) sebesar 0,842, yang berarti bahwa kemampuan variabel pendidikan dan pelatihan $(\mathrm{X})$ dapat mempengaruhi variabel kinerja karyawan (Y) sebesar 84,2\%.

Kata kunci: pendidikan, pelatihan, kinerja karyawan

\section{Latar Belakang}

Pada era globalisasi saat ini,banyak tantangan yang harus dihadapi oleh perusahaan dalam rangka memenangkan persaingan. Baik perusahaan kecil, menengah maupun besar di Indonesia, untuk dapat bertahan dan memenangkan persaingan dituntut memiliki keunggulan bersaing. Salah satu faktor yang dapat dijadikan pegangan perusahaan dalam menciptakan keunggulan bersaing adalah dengan keunggulan produk dan sumber daya manusia yang berkualitas. 
Langkah awal untuk mendapatkan sumber daya manusia yang berkualitas adalah dimulai dengan menarik dan memilih tenaga kerja yang sesuai dengan standar personalia perusahaan. Standar ini merupakan persyaratan minimal yang harus dipenuhi agar seorang karyawan dapat mengerjakanpekerjaannya dengan baik. Langkah selanjutnya untuk terus meningkatkan sumber daya manusia yang terampil dan berkemampuan tinggi salah satunya dengan memberikan pendidikan dan pelatihan terhadap setiap pelaku organisasi secara berkesinambungan dengan metode yang sistematis.

UD. Yamaha Istana Sepeda Balangansejak tahun 1981 mulai menjual sepeda motor merk Yamaha hingga saat ini, dan berkembang berupaya memenuhi kebutuhan konsumen dengan produk-produk Yamaha yang sesuai dengan misi perusahaan yaitu "Semakin di depan" yang mendorong Yamaha untuk selalu unggul dalam kompetisi produk, kualitas, layanan, serta layanan pasca penjualan. Sampai saat ini perusahaan masih berperan sebagai penjual sepeda motor merk Yamaha, penyebaran produknya di kota Balangan dan kota-kota lainnya.

Penurunan kinerja karyawan salah satunya adalah masalah kedisiplinan. Selain kedisiplinan, kurang cekatan karyawan dalam menangani atau melayani konsumen, kurangnya rasa tanggung jawab karyawan terhadap pelanggan dan sering terjadi kerusakan peralatan kerja yang digunakan oleh karyawan. Karena itu, kinerja karyawan masih perlu ditingkatkan agar tujuan perusahaan dapat tercapai dengan maksimal, untuk mencapai hasil yang maksimal dalam menjalankan pekerjaan, perlu adanya pengembangan karyawan dengan melakukan pendidikan dan pelatihan.

Pentingnya pelatihan dan pengembangan menghendaki kegiatan ini dilakukan dengan memalui langkah-langkah tertentu, yaitu berdasarkan kebutuhan (kebutuhan organisasi, kebutuhan tugas dan kebutuhan karyawan). Penentuan tujuan, materi pelatihan dan pemilihan metode yang tepat sangat diperlukan dalam pengelolaan MSDM di perusahaan.

\section{Kajian Literatur}

Kajian literatur diisi dengan teori-teori yang berkaitan dengan penelitian saudara. Karena keterbatasan halaman, cukup masukkan teori yang betul-betul dibutuhkan saja, seperti pengertian dari variabel, indikator yang digunakan, serta perdebatan dari penelitian terdahulu tentang hubungan antar variabel yang diteliti. Semua literatur ditulis dalam sub bab yang sama (jangan membuat anak sub bab lagi).

Pendidikan dan pelatihan adalah salah satu usaha yang dapat dilakukan oleh perusahaan untuk memenuhi kebutuhan tenaga kerja yang bermutu dan mampu melaksanakan tugasnya dengan baik.

Pendidikan dan pelatihan perlu dilaksanakan oleh setiap perusahaan secara berkesinambungan agar tenaga kerja yang dimiliki benar-benar bermutu dan mempunyai keahlian serta keterampilan yang sesuai dengan tuntutan pekerjaannya. Disamping itu, perkembangan eksternal maupun internal yang selalu berubah sering mengakibatkan kesenjangan antara tuntutan perusahaan atau pekerjaan dengan kemampuan tenaga kerja, yang mana hal ini juga merupakan salah satu sebab kebutuhan akan pendidikan dan pelatihan yang berkesinambungan.

Pendidikan dan pelatihan merupakan upaya untuk pengembangan sumber daya manusia. Penggunaan dalam suatu institusi atau organisasi biasanya disingkat menjadi diklat (pendidikan dan pelatihan). Pelaksanan pendidikan dan pelatihan diarahkan kepada peningkatan keterampilan, pengetahuan serta perubahan sikap atau perilaku karyawan.Melalui proses belajar yang diterapkan pada pendidikan dan pelatihan diharapkan adanya perubahan pada peserta yaitu dari kurang tahu menjadi tahu, dari kurang terampil menjadi terampil serta dari sikap dan perilaku negatif menjadi positif dan sebagainya. 
Hasibuan (2014:69), menyatakan pendidikan dan pelatihan adalah suatu usaha untuk meningkatkan kemampuan teknis, teoretis, konseptual, dan moral karyawan sesuai dengan kebutuhan pekerjaan atau jabatan. Pendidikan meningkatkan keahlian teoretis, konseptual, dan moral karyawan, sedangkan pelatihan bertujuan untuk meningkatkan keterampilan teknis pelaksanaan pekerjaan karyawan.

Pelatihan dalam kamus bahasa Indonesia diartikan sebagai pelajaran untuk membiasakan atau memperoleh suatu keterampilan. Menurut Wexkley dan Yulk dalam Widodo (2015:80) pelatihan adalah mengacu pada hal-hal yang berhubungan dengan usaha berencana yang dilaksanakan untuk mencapai penguasaan keterampilan, pengetahuan dan sikap karyawan atau anggota karyawan.

Berasarkan pengertian diatas dimaksud dengan keterampilan adalah suatu proses untuk membentuk dan membekali karyawan dengan menambah keahlian, kemampuan, pengetahuan dan perilakunya yang berhubungan dengan pekerjaan.

Tujuan pendidikan dan pelatihan sebagaimana yang dikemukakan oleh Hasibuan (2014:70) adalah sebagai berikut:

1. Produktivitas Kerja

Pendidikan dan pelatihan yang dilakukan bertujuan agar produktivitas kerja karyawan akan meningkat, kualitas dan kuantitas produksi semakin baik, karena technical skill, human skill, dan managerial skill karyawan yang semakin baik.

2. Efisiensi

Pendidikan dan pelatihan karyawan bertujuan untuk meningkatkan efisiensi tenaga, waktu, dan bahan baku. Pemborosan berkurang, biaya produksi relatif kecil sehingga daya saing perusahaan semakin besar.

3. Kerusakan

Pendidikan dan pelatihan karyawan bertujuan untuk mengurangi kerusakan barang, produksi dan mesin-mesin karena karyawan semakin ahli dan terampil dalam melaksanakan pekerjaannya.

4. Kecelakaan

Pendidikan dan pelatihan bertujuan untuk mengurangi tingkat kecelakaan karyawan, sehingga jumlah biaya pengobatan yang dikeluarkan perusahaan berkurang.

5. Pelayanan

Pendidikan dan pelatihan bertujuan untuk meningkatkan pelayanan yang lebih baik dari karyawan kepada nasabah perusahaan, karena pemberian pelayanan yang baik merupakan daya tarik yang sangat penting bagi rekan-rekan perusahaan bersangkutan.

6. Moral

Pendidikan dan pelatihan yang dilakukan bertujuan agar moral karyawan akan lebih baik karena keahlian dan keterampilannya sesuai dengan pekerjaannya. Sehingga mereka antusias untuk menyelesaikan pekerjaannya dengan baik.

7. Karier

Pendidikan dan pelatihan bertujuan agar kesempatan untuk meningkatkan karier karyawan semakin besar, karena keahlian, keterampilan, dan prestasi kerjanya lebih baik.

8. Konseptual

Pendidikan dan pelatihan dilakukan bertujuan agar manajer semakin cakap dan cepat dalam mengambil keputusan yang lebih baik, karena technical skill, human skill, dan managerial skill-nya lebih baik.

9. Kepemimpinan

Pendidikan dan pelatihan dilakukan bertujuan agar kepemimpinan seorang manajer akan lebih baik, human relation-nya lebih luwes, motivasinya lebih terarah sehingga pembinaan kerjasama vertikal dan horisontal semakin harmonis. 
10. Balas Jasa

Pendidikan dan pelatihan bertujuan agar balas jasa (gaji, upah insentif, dan benefits) karyawan akan meningkat karena prestasi kerja mereka semakin besar.

11. Konsumen

Pendidikan dan pelatihan karyawan akan memberikan manfaat yang baik bagi masyarakat konsumen karena mereka akan memperoleh barang atau pelayanan yang lebih bermutu.

Menurut Kasmir (2016:137) agar diperoleh hasil yang baik artinya karyawan yang dilatih akan mendapatkan manfaat sesuai dengan tujuan perusahaan. Dalam peraktiknya teknik pelatihan karyawan ada dua, yaitu sebagai berikut:

1. Metode Praktis (On The Job Training)

Metode ini memberikan pelatihan kepada karyawan sambil bekerja. Artinya karyawan langsung dilatih dengan pekerjaan yang ditanganinya, biasanya metode ini diberikan karena kondisi kebutuhan perusahaan mendesak. Pertimbangan lainnya karena peserta pelatihan dinilai sudah memiliki pengalaman tertentu, tinggal menyesuaikan diri dan memperdalam dengan pekerjaan yang baru. Dalam Job Training calon karyawan akan diberikan pengetahuan tentang:

a. Struktur organisasi yang ada diperusahaan

b. Bekerja dalam berbagai macam keterampilan

c. Melatih karyawan tentang cara melaksanakan pekerjaan

d. Magang di bagian-bagian tertentu

e. Penugasan tugas sementara.

2. Teknik Presentasi dan Metode Simulasi.

Teknik presentasi memberikan pemahaman kepada karyawan melalui tatap muka secara langsung. Artinya pelatihan diberikan di dalam ruangan tertentu. Intruktur memberikan materi langsung ke peserta pelatihan dan peserta dapat menanggapi materi yang diberikan. Model pelatihan semacam ini dapat dilakukan dengan cara:

a. Sistem perkuliahan di kelas

b. Presentasi video

c. Konfrensi

d. Workshop

e. Atau gabungan dari salah satunya.

Menurut Hasibuan (2014:83), Indikator dari metode pendidikan dan pelatihan adalah sebagai berikut::

1. Prestasi Kerja Karyawan

Apabila prestasi kerja atau produktivitas kerja karyawan setelah mengikuti pendidikan dan pelatihan, baik kualitas maupun kuantitas kerjanya meningkat, berarti metode pendidikan dan pelatihan yang diterapkan cukup baik. Tetapi jika prestasi kerjanya tetap, berarti metode pendidikan dan pelatihan yang dilakukan kurang baik sehingga perlu diadakan perbaikan.

2. Kedisiplinan Karyawan

Apabila kedisiplinan karyawan setelah mengikuti pendidikan dan pelatihan semakin baik berarti metode pendidikan dan pelatihan yang dilakukan baik, tetapi apabila kedisiplinan tidak meningkat berarti metode pendidikan dan pelatihan yang diterapkan kurang baik. 


\section{Absensi Karyawan}

Apabila absensi karyawan setelah mengikuti pendidikan dan pelatihan menurun, maka metode pendidikan dan pelatihan yang diterapkan cukup baik. Sebaliknya jika absensi karyawan tetap atau bahkan meningkat, berarti metode pendidikan dan pelatihan yang diterapkan kurang baik.

4. Tingkat Kerusakan Produksi, Alat, dan Mesin-Mesin

Apabila tingkat kerusakan produksi, alat, dan mesin-mesin setelah karyawan mengikuti pendidikan dan pelatihan berkurang, maka metode pendidikan dan pelatihan itu sudah cukup baik.Sebaliknya jika tingkat kerusakan produksi, alat, dan mesin-mesin tetap berarti metode pendidikan dan pelatihan yang diterapkan kurang baik.

5. Tingkat Kecelakaan Karyawan

Tingkat kecelakaan karyawan harus berkurang setelah mereka mengikuti pendidikan dan pelatihan. Jika tingkat kecelakaan karyawan tidak berkurang berarti metode pendidikan dan pelatihan yang diterapkan kurang baik sehingga perlu dilakukan perbaikan.

6. Tingkat Pemborosan Bahan Baku, Tenaga dan Waktu

Tingkat pemborosan bahan baku, tenaga, dan waktu berkurang atau efisiensi semakin baik maka metode pendidikan dan pelatihan yang diterapkan itu cukup baik. Sebaliknya, jika tingkat pemborosan bahan baku, tenaga, dan waktutetap berarti metode pendidikan dan pelatihan itu kurang baik.

7. Tingkat Kerja Sama Karyawan

Tingkat kerja sama karyawan harus semakin serasi, harmonis dan baik setelah mereka mengikuti pendidikan dan pelatihan, tetapi jika tidak ada perbaikan kerja sama maka metode pendidikan dan pelatihan itu kurang baik.

8. Tingkat Upah Insentif Karyawan

Apabila upah insentif karyawan meningkat setelah mengikuti pendidikan dan pelatihan, maka metode pendidikan dan pelatihan yang diterapkan sudah cukupbaik. Sebaliknya jika upah insentif karyawantetap berarti metode pendidikan dan pelatihan itu kurang baik.

\section{Prakarsa Karyawan}

Prakarsa karyawan harus meningkat setelah mengikuti pendidikan dan pelatihan, jika tidak meningkat berarti metode pendidikan dan pelatihan itu kurang baik. Dalam hal ini, karyawan diharapkan dapat bekerja mandiri serta bisa mengembangkan kreativitasnya.

10. Kepemimpinan dan Keputusan Manajer

Kepemimpinan atau keputusan-keputusan yang ditetapkan oleh Manajer setelah dia mengikuti pendidikan dan pelatihan harus semakin baik, kerja sama semakin serasi, sasaran yang dicapai semakin besar, ketegangan-ketegangan berkurang, serta kepuasan kerja karyawan meningkat.

Apabila hal-hal di atas tercapai berarti metode pendidikan dan pelatihan yang dilaksanakan itu baik. Sebaliknya, jika hal-hal di atas tidak tercapai berarti metode pendidikan dan pelatihan yang diterapkan kurang baik.

Selanjutnya, landasan yang sesungguhnya dalam suatu organisasi adalah kinerja. Jika tidak ada kinerja di seluruh bagian organisasi, maka tujuan tidak dapat tercapai. Kinerja perlu dijadikan sebagai bahan evaluasi bagi pemimpin atau Manajer. 
Pengertian kinerja yang dimaksud disini adalah hasil kerja, yaitu kemampuan dan kecakapan pekerja untuk melakukan suatu pekerjaan yang dibebankan atau ditugaskan kepadanya dengan pengetahuan dan keahlian yang dimiliki oleh pekerja tersebut. Kinerja karyawan merupakan sesuatu yang diharapkan oleh perusahaan dari karyawannya dalam rangka mengembangkan dan melancarkan setiap pekerjaan perusahaan sehingga tujuan perusahaan tercapai.

Hasibuan (2014:94), menyatakan kinerja adalah suatu hasil kerja yang dicapai seseorang dalam melaksanakan tugas-tugas yang dibebankan kepadanya yang didasarkan atas kecakapan, pengalaman dan kesungguhan.Widodo (2015: 131) kinerja adalah hasil pelaksanaan suatu pekerjaan, baik bersifat fisik/material maupun non fisik/non material. Menurut Fahmi (2016: 127) kinerja adalah hasil yang diperoleh oleh suatu organisasi baik organisasi tersebut bersifat profit oriented dan nonprofit oriented yang dihasilkan selama satu periode tertentu.

Berdasarkan pendapat diatas maka dapat disimpulkan; kinerja perilaku yang nyata, yang ditampilkan setiap orang sebagai prestasi kerja yang dihasilkan oleh pegawai/karyawan sesuai peraturan dalam organisasi. Menurut Simanjuntak dalam Widodo (2015:133) kinerja dipengaruhi:

1. Kualitas dan kemampuan pegawai, yaitu: hal-hal yang berhubungan dengan pendidikan dan pelatihan, etos kerja, motivasi kerja, sikap mental dan kondisi fisik pegawai

2. Sarana pendukung, yaitu: hal yang berhubungan dengan lingkungan kerja (keselamatan kerja, kesehatan kerja, sarana produksi, teknologi) dan hal-hal yang berhubungan dengan kesejahteraan pegawai (upah/gajih, jaminan sosial, keamanan kerja)

3. Supra Sarana, yaitu: hal-hal yang berhubungan dengan kebijaksanaan pemerintah dan hubungan industrial.

Menurut Hasibuan (2014:95), bahwa unsur-unsur yang dinilai dari kinerja karyawan adalah:

1. Kesetiaan

Penilai mengukur kesetiaan karyawan terhadap pekerjaannya, jabatannya, dan organisasi.

Kesetiaan ini dicerminkan oleh kesediaan karyawan menjaga dan membela organisasi di dalam maupun di luar pekerjaan dari rongrongan orang yang tidak bertanggung jawab.

2. Prestasi Kerja

Penilai menilai hasil kerja baik kualitas maupun kuantitas yang dapat dihasilkan karyawan tersebut dari uraian pekerjaannya.

3. Kejujuran

Penilai menilai kejujuran dalam melaksanakan tugas-tugasnya memenuhi perjanjian baik bagi diri sendiri maupun terhadap orang lain seperti kepada para bawahannya.

4. Kedisiplinan

Penilai menilai disiplin karyawan dalam mematuhi peraturan-peraturan yang ada dan melakukan pekerjaannya sesuai dengan instruksi yang diberikan kepadanya.

5. Kreativitas

Penilai menilai kemampuan karyawan dalam mengembangkan kreativitasnya untuk menyelesaikan pekerjaannyasehingga bekerja lebih berdaya guna dan berhasil guna. 


\section{Kerja Sama}

Penilai menilai kesediaan karyawan berpartisipasi dan bekerja sama dengan karyawan lainnya secara vertikal atau horisontal di dalam maupun di luar pekerjaan sehingga hasil pekerjaan akan semakin baik.

7. Kepemimpinan

Penilai menilai kemampuan untuk memimpin, berpengaruh, mempunyai pribadi yang kuat, dihormati, berwibawa, dan dapat memotivasi orang lain atau bawahannya untuk bekerja secara efektif.

8. Kepribadian

Penilai menilai karyawan dari sikap perilaku, kesopanan, periang, disukai, memberi kesan menyenangkan, memperlihatkan sikap yang baik, serta berpenampilan simpatik dan wajar.

\section{Prakarsa}

Penilai menilai kemampuan berpikir yang asli dan berdasarkan inisiatif sendiri untuk menganalisa, menilai, menciptakan, memberikan alasan, mendapatkan kesimpulan, dan membuat keputusan penyelesaian masalah yang dihadapinya.

10. Kecakapan

Penilai menilai kecakapan karyawan dalam menyatukan dan menyelaraskan bermacammacam elemen yang semuanya terlibat di dalam penyusunan kebijaksanaan dan di dalam situasi manajemen.

11. Tanggung Jawab

Penilai menilai kesediaan karyawan dalam mempertanggungjawabkan kebijaksanaannya, pekerjaan dan hasil kerjanya, sarana dan prasarana yang dipergunakannya serta perilaku kerjanya.

\section{Metode Penelitian}

Variabel yang dibahas adalah Pendidikan dan Pelatihanterhadap Kinerja Karyawan. Sampel dalam penelitian ini ialah 36 responden yang berasal dari karyawan divisi layanan UD. Yamaha Istana Sepeda Balangan.Pengambilan sampel dengan menggunakanProbability Sampling yaitudengan memilih langsung seluruh karyawan. Data dianalisis dengan menggunakan metode kualitatif dan metode kuantitatif dengan menggunakan rumus analisis regresi sederhana,uji T-tes dan uji Koefisien Deterrminasi (R2) menggunakan bantuan software SPSS 18 untuk windows dengan persamaan regersi : $\mathrm{Y}=\mathrm{a}+\mathrm{bX}$.

\section{Hasil Penelitian}

Butir-butir angket yang valid dan reliabel kemudian dilaksanakan pengolahan data dengan menggunakan program SPSS (Statisitical Product and Service Solution) versi 18 yang hasilnya dapat dilihat pada tabel 1 .

Tabel 1. Estimasi Regresi Sederhana

\begin{tabular}{|c|c|c|c|c|}
\hline Variabel & Koefisien Regresi & Beta & $T_{\text {hitung }}$ & Sig. \\
\hline Constant & 5,221 & & & \\
\hline Pendidikan dan Pelatihan $(\mathrm{X})$ & 0,946 & 0,946 & 13,443 & 0,000 \\
\hline Koefisien Determinasi $\quad: 0,842$ & & & & \\
\hline $\mathrm{T}_{\text {tabel }} 5 \%(36-2)$ & & & & \\
\hline & & $\begin{array}{r}\text { lid 5, No } \\
\text { ISS }\end{array}$ & $\begin{array}{l}\text { ember } 2019 \\
\text { ne } 2615-2134\end{array}$ & 359 \\
\hline
\end{tabular}


Berdasarkan tabel 1. hasil estimasi regresi linier sederhana didapatkan persamaan regresi sederhana adalah :

$Y=5,221+0,946 X$

Pada tabel 1 dapat diketahui nilai a adalah 5,221 dan nilai b adalah 0,946. Nilai a sebesar 5,221 artinya apabila tidak ditambah variabel pendidikan dan pelatihan (X) maka nilai variabel kinerja karyawan (Y) akan tetap sebesar 5,221. Nilai b sebesar 0,946 artinya apabila ditambah variabel pendidikan dan pelatihan (X) maka nilai variabel kinerja karyawan (Y) akan bertambah sebesar 0,946.

Selanjutnya, dilakukan Uji t. Uji t adalah uji yang dipakai untuk mengetahui pengaruh secara parsial antara variabel Pendidikan dan Pelatihan (X) dengan variabel Kinerja Karyawan (Y). Diketahui nilai df $=(\mathrm{n}-\mathrm{k})=36-2=34$, dan taraf signifikan 5\% (5\%:2=0,025), didapatkan nilai t-tabelsebesar 2,03224 (2,032).

Nilai t-hitung $(13,443)$ lebih besar dari t-tabel $(2,032)$ atau karena nilai Sig. variabel Pendidikan dan Pelatihan $(0,000)$ lebih kecil dari nilai alpha $(\alpha=0,05)$ dengan arah koefisien positif, maka dapat disimpulkan bahwa Variabel Pendidikan dan Pelatihan berpengaruh positif signifikan terhadap Variabel Kinerja Karyawan UD. Yamaha Istana Sepeda balangan pada taraf uji signifikansi 5\%. Dengan demikian, hipotesis yang diajukan dalam penelitian secara keseluruhan diterima.

Tabel 2. Model Summary ${ }^{\mathrm{b}}$

\begin{tabular}{ccccc}
\hline Model & $R$ & $R$ Square & Adjusted $R$ Square & Std. Error of the Estimate \\
\hline 1 &, $917^{\text {a }}$ &, 842 &, 837 & 3,65653
\end{tabular}

a. Predictors: (Constant), Pendidikan dan Pelatihan (X)

b. Dependent Variable: Kinerja Karyawan (Y)

Koefisien determinasi adalah sebesar 0,842 , hal ini berarti bahwa kinerja karyawan dapat dipengaruhi oleh variabel pendidikan dan pelatihan sebesar $84,2 \%$ atau variabel pendidikan dan pelatihan mempengaruhi variabel kinerja karyawan sebesar $84,2 \%$. Sedangkan sisanya sebesar $15,8 \%$ dipengaruhi oleh variabel lain yang tidak termasuk dalam penelitian ini.

\section{Kesimpulan dan Keterbatasan Penelitian}

Berdasarkan hasil penelitian yang dilakukan pada UD. Yamaha Istana Sepeda Balangan, maka kesimpulan yang dapat dikemukakan dalam penelitian ini adalah sebagai berikut:

1. Hasil perhitungan persamaan regresi pada penelitian ini adalah: $Y=5,221+0,946 X$. Nilai a (konstanta) adalah 5,221 dannilai b adalah 0,946. Nilai a sebesar 5,221 artinya apa bila tidak ditambah variabel pendidikandan pelatihan (X) maka nilai variabel kinerja karyawan (Y) akan tetap sebesar 5,221. Nilai b sebesar 0,946 artinya apa bila ditambah variabel pendidikan dan pelatihan (X) maka nilai variabel kinerja karyawan $(\mathrm{Y})$ akan bertambah sebesar 0,946.

2. Pada perhitungan uji tdengan taraf signifikansi 5\%, diketahui bahwa nilai t-hitung lebih besar dari t-tabel $(13,443>2,032)$ dan nilai Sig.variabel Pendidikan dan Pelatihan $(0,000)<$ nilai alpha $(\alpha=0,05)$ dengan arah koefisien positif. Dengan demikian Variabel Pendidikan dan Pelatihan berpengaruh positif signifikan terhadap Variabel Kinerja Karyawan UD. Yamaha Istana Sepeda balangan pada taraf uji signifikansi 5\%. Sehingga hipotesis yang diajukan dalam penelitian secara keseluruhan diterima (Ha diterima dan Ho ditolak). 
3. Hasil perhitungan koefisien determinasi diketahui nilai koefisien determinasi adalah sebesar 0,842 . Hal ini berarti bahwa variasi kinerja karyawan dapat dijelaskan oleh variasi pendidikan dan pelatihan sebesar $84,2 \%$ atau variabel pendidikan dan pelatihan mempengaruhi variabel kinerja karyawan sebesar $84,2 \%$. Sedangkan sisanya sebesar $15,8 \%$ dipengaruhi oleh variabel lain yang tidak termasuk dalam penelitian ini.

Berdasarkan pada hasil penelitian yang telah dilakukan, terdapat beberapa saran sebagai masukan dalam pencapaian keberhasilan pendidikan dan pelatihan yang diikuti terhadap kinerja karyawan pada UD. Yamaha Istana Sepeda Balanganadalah sebagai berikut:

1. Pendidikan dan pelatihan merupakan salah satu upaya dalam meningkatkan sumber daya manusia pada suatu organisasi atau perusahaan agar tercipta sumber daya manusia yang bermutu. Untuk itu perlu adanya perencanaan peningkatan pengetahuan, kemampuan, dan keterampilan karyawan secara berkala dan berkesinambungan, sesuai dengan kebutuhan karyawan.

2. Perlu adanya evaluasi yang dilakukan oleh perusahaan terhadap karyawan yang telah mengikuti pendidikan dan pelatihan sehingga dapat mengetahui apa yang telah didapatkan karyawan semasa pendidikan dan pelatihan, agar mengetahui apa yang perlu diperbaiki lagi untuk meningkatkan kinerja karyawan.

3. Kesadaran dan tanggung jawab karyawan UD. Yamaha Istana Sepeda Balanganterhadap pekerjaannya harus ditingkatkan lagi, sehingga hasil pekerjaan menjadi lebih maksimal.

\section{DAFTAR PUSTAKA}

Ardana, I Komang, Ni Wayan Mujiati dan I Wayan Mudiartha Utama.2012. Manajemen Sumber Daya Manusia. Edisi 1. Yogyakarta: Graha Ilmu.

Fahmi, Irham. 2016. Manajemen Sumber Daya manusia Teori dan Aplikasi. Bandung: Alfabeta.

Hasibuan, Malayu S.P. 2014. Manajemen Sumber Daya Manusia. Edisi Revisi Cetakan ke-18. Jakarta: PT. Bumi Aksara.

Kasmir. 2016. Manajemen Sumber Daya Manusia. Jakarta; Rajawali.

Marwansyah. 2014. Manajemen Sumber Daya Manusia. Bandung; Alfabeta.

Sugiyono. 2014. Metode Penelitian Bisnis: Pendekatan Kuantitatif, Kualitatif dan R\&D. Cetakan ke-18. Bandung: Alfabeta.

Sugiyono. 2011. Metode Penelitian Kuantitatif, Kualitatif dan R\&D. Cetakan ke-14. Bandung: Alfabeta.

Suharyadi dan Purwanto S.K. 2013. STATISTIKA: Untuk Ekonomi dan Keuangan Modern. Edisi 2. Jakarta: Salemba Empat.

Suliyanto. 2011. Ekonometrika Terapan-Teori dan Aplikasi dengan SPSS. Edisi 1. Yogyakarta : CV. Andi Offset.

Trihendradi, C. 2010. Step by Step SPSS 18 Analisis Data Statistik. Edisi 1. Yogyakarta: CV. Andi Offset.

Widodo Suparmo Eko, 2015. Manajemen Pengembangan Sumber Daya Manusia. Yogyakarta: Pustaka Pelajar.

Zainal, Veithzal Rivai, dkk. 2014. Manajemen Sumber Daya Manusia untuk Perusahaan: Dari Teori ke Praktik. Edisi 3. Jakarta : Rajawali Pers. 